\title{
COUNTERMEASURES FOR THE RIVER MOUTH CLOSING OF ISHIKARI RIVER, JAPAN
}

\author{
HIROSHI GOTOH ${ }^{1}$, OSAMU HANADA ${ }^{1}$, TADAYUKI YAMAMOTO ${ }^{2}$, SHOZO TOMAKI ${ }^{3}$, \\ MINORU TANAKA ${ }^{3}$, OSAMU ISHIKAWA ${ }^{3} \&$ MITSUO TAKEZAWA ${ }^{1}$ \\ ${ }^{1}$ Nihon University, Japan \\ ${ }^{2}$ Chuo College of Technology, Japan \\ ${ }^{3}$ Ishikarigawa Workshop, Japan
}

\begin{abstract}
The Ishikari River originates in Mount Ishikari in the Taisetsu Mountain Range and flows $268 \mathrm{~km}$ through Asahikawa and Sapporo before entering Ishikari Bay in the Sea of Japan on the west coast of Hokkaido, Japan. The Ishikari River drains a catchment area of $14,330 \mathrm{~km}^{2}$ in western Hokkaido, including the Ishikari Plain with an area of $3800 \mathrm{~m}^{2}$. The large Ishikari River Basin supports a wide variety of life and a large human population. Despite implementation of flood control measures since 1834, several floods have occurred. Preventing the formation of spits has been particularly important in preventing river mouth closure of the Ishikari River. The coastline of Hokkaido along Ishikari Bay has large areas of quicksand that were deposited by the Ishikari River at a rate of approximately 2,000,000 $\mathrm{m}^{3}$ of sand annually with sandy beaches extending more than $24 \mathrm{~km}$ to the north and south of the river mouth. Decreased river discharge due to use of river water for drinking water and irrigation along with deposition of sediment by longshore currents along the coast has increased the incidence of mouth closure of the Ishikari River. Many countermeasures against river mouth closure have been carried out in the Ishikari River basin, but these efforts have not been completely effective for preventing river mouth closure. However, construction of the Ishikari Bay new port $7.5 \mathrm{~km}$ south of the Ishikari River mouth as part of the Third Hokkaido Comprehensive Development Plan approved by the Japanese Cabinet in July 1970 has decreased longshore sediment transport, which has stabilized the Ishikari River mouth and reduced the incidence of river mouth closure.
\end{abstract}

Keywords: river mouth, Ishikari river, Ishikari Bay new port, longshore current, longshore sediment transport.

\section{INTRODUCTION}

At the river mouth, flow is affected by longshore currents and the outflow from the river. River mouth closure in areas with sandy coastal areas occurs under the conditions of a strong longshore current and low outflow from the river due to the development of a sand spit, which is a sandy deposit built up into a landform at the river mouth. At one end, the spit is connected to land and the other end extends out into the body of water. Sand spits at the river mouth prevent waves and salt water from intruding into the river, but excessive development of the sand spit causes serious problems such as water level rise during floods and difficulty navigating through the river mouth.

Longshore drifting is complemented by longshore currents, which transport sediment through water alongside the coast. These currents are set in motion by waves hitting the coast at an oblique angle that causes littoral drift and sediment transport. As spits grow, the water behind them is sheltered from wind and waves, and a salt marsh is likely to develop.

To maintain an open river mouth, it is important to understand the river mouth morphology behavior in response to waves, tides, river flow and the construction of structures around a river mouth [1], [2]. The changes in the river mouth of the Ishikari River are described in this paper. 


\section{DESCRIPTION OF ISHIKARI RIVER}

The Ishikari River at $268 \mathrm{~km}$ long is the longest in Hokkaido, Japan (Fig. 1). The river drains an area of 14,330 $\mathrm{m}^{2}$ and has a total discharge of around $14.8 \mathrm{~km}^{3}$ per year, making it the second largest in Japan [3]. The river originates from Mount Ishikari in the Taisetsu Mountain Range and flows through Asahikawa and Sapporo to the Japan Sea (Figs 2 and 3). Major tributaries of the river include the Chyubetsu, Ryuu, Sorachi and Toyohira rivers. Until 40,000 years ago, the Ishikari River flowed into the Pacific Ocean near Tomakomai, and it once meandered through the Ishikari plain and was as long as the Shinano River, the longest river in Japan. Major construction shortened the river by $100 \mathrm{~km}$, leaving many oxbow lakes in the plain (Fig. 3). The river mouth is affected by longshore current, and the sediment discharge loads from the river. Closure of the river mouth leads to flooding, and although construction of a training jetty and shortening the river are countermeasures, they are not solutions to the root of the problem [3]-[5].

\section{ISHIKARI COAST AND ISHIKARI BAY NEW PORT}

The Ishikari coastline is covered with sandy beaches stretching approximately $24 \mathrm{~km}$ from Zenibako to Chizukari and has sea floor topography characterized by contours running parallel to the shoreline as shown in Fig. 4. The beach is comparatively gently sloping. The frequency wave height and direction observed from 1996 to 2000 at a point $5 \mathrm{~km}$ offshore from the new port at Ishikari Bay by the Hokkaido Development Agency of the Japanese Government is shown in Fig. 5 [7], [8].

The mean flow in Ishikari Bay in May 1980 obtained from continuous observations over a 30-day period [8] showed that flow was in a southwest to northeast direction. A simulation of the projected tidal currents with the completed Ishikari Bay New Port (Fig. 6) shows the maximum velocity of tidal currents from the northeast to the southwest outside the harbor of approximately $10 \mathrm{~cm} / \mathrm{s}$, while the velocity of the tidal currents in the harbor is considerably less.

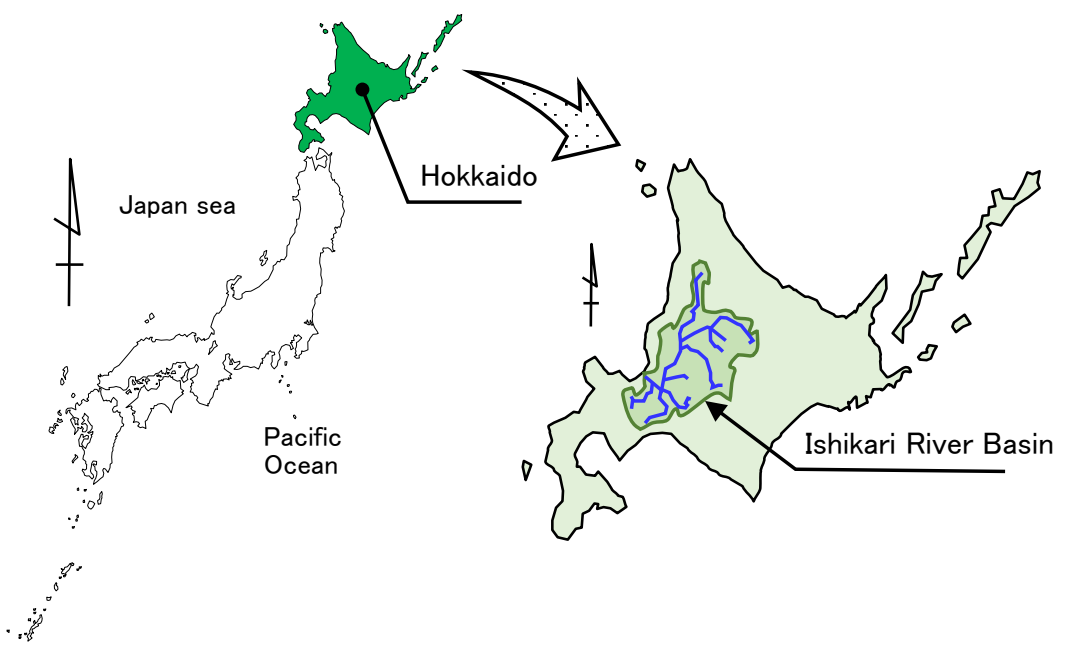

Figure 1: Map of Japan showing Hokkaido and Ishikari River [6]. 


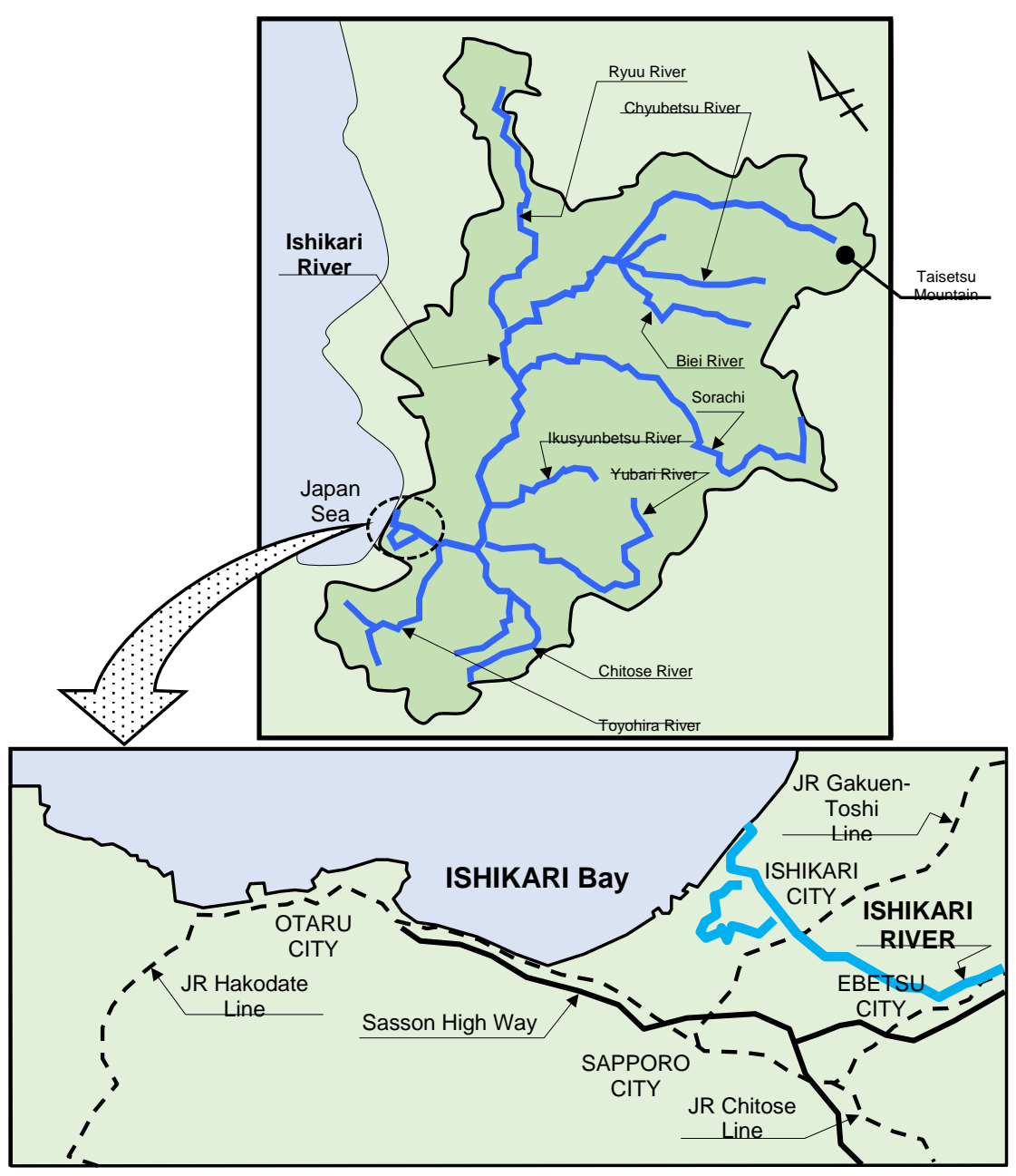

Figure 2: Ishikari River Basin, Ishikari Bay and Ishikari coast.

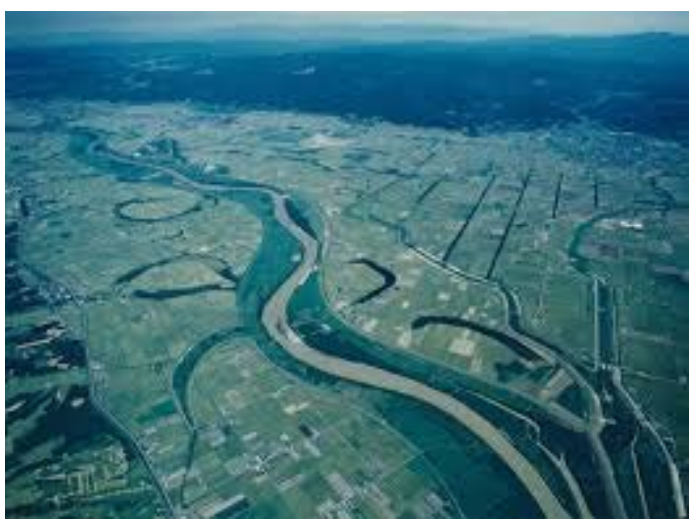

Figure 3: Meandering midstream region and oxbow lakes of the Ishikari River. 


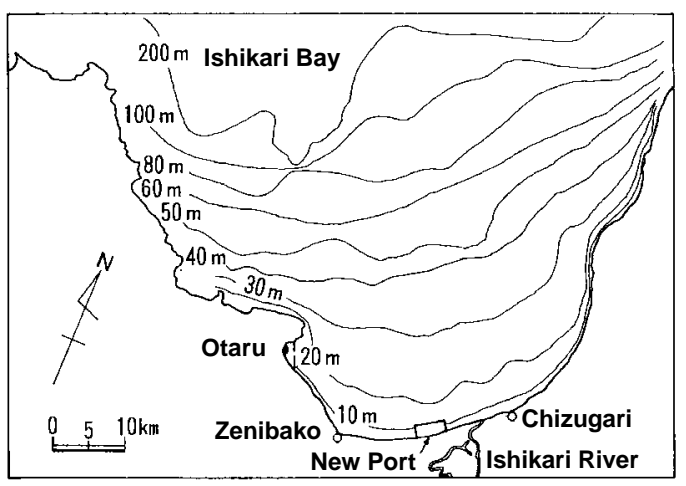

Figure 4: Depth contours in Ishikari Bay.

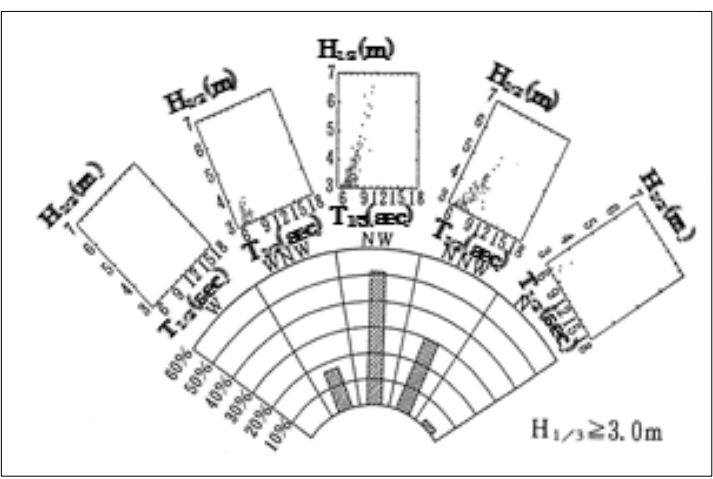

Figure 5: Frequency, height and direction of waves at $5 \mathrm{~km}$ offshore from the new port at Ishikari Bay from 1996 to 2000.

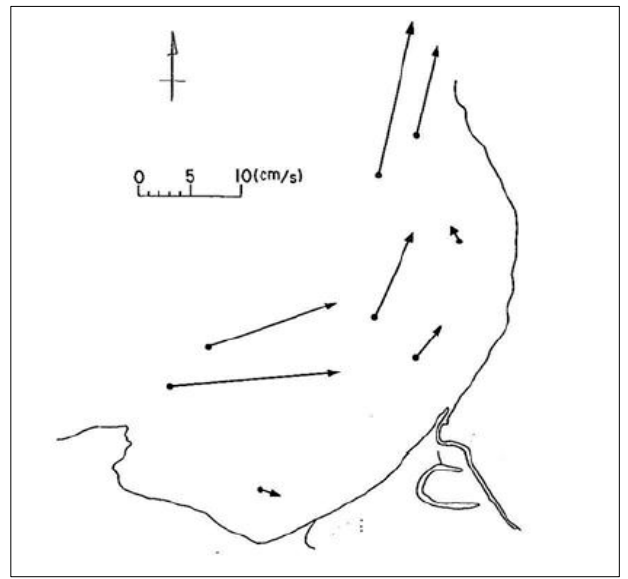

Figure 6: Mean flow within Ishikari Bay. 


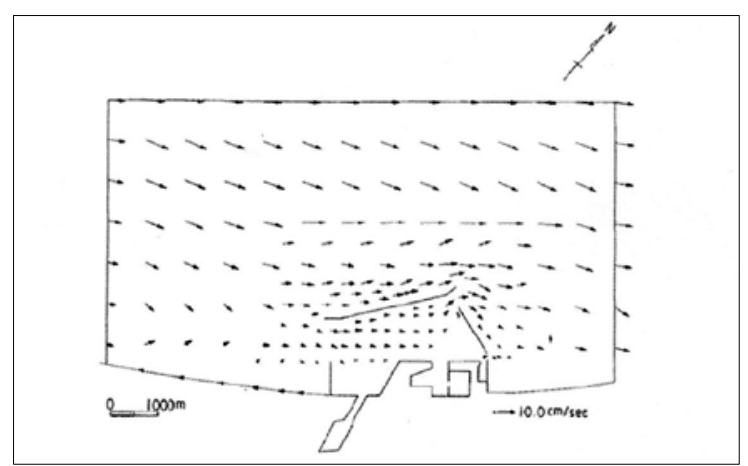

Figure 7: Nearshore currents near the Ishikari Bay new port.

Fig. 7 depicts the nearshore current around the Ishikari Bay New Port. Nearshore currents were calculated by the finite element method using the following parameters: wave height, $\mathrm{H}=4.7 \mathrm{~m}$, wave period, $\mathrm{T}=8.6 \mathrm{~s}$ and wave direction 310 in degree from the north. The longshore current near the shoreline of the west coast moves northeast, and the rip current that is formed along the west breakwater is shown in Fig. 7 [8], [9]. Ishikari Bay is an inlet of the Sea of Japan on the western coast of Hokkaido, Japan. The Ishikari Plain of the area 3,800 $\mathrm{m}^{2}$ is located at the back of Ishikari Bay, and the Ishikari River flows through the plain and discharges into Ishikari Bay. The Ishikari coast was filled by quicksand discharged from the Ishikari River as part of the Ishikari Plain, and the sandy beach covers over $24 \mathrm{~km}$ at either side of the Ishikari River. The Ishikari Bay New Port was planned and constructed at $7.5 \mathrm{~km}$ away from the mouth of Ishikari River following approval of the Third Hokkaido Comprehensive Development Plan the Cabinet in July 1970. Under the plan, the Ishikari Bay area, which is adjacent to Sapporo, and the surrounding area in the center of Hokkaido was considered to be a highly advantageous location for maximizing the existing distribution function for physical goods. To establish a new base for distribution and manufacturing in the region, therefore, construction of the port and the development of the immediate surrounding area were begun as major development projects in Hokkaido. After being designated as major port in April 1973, full-scale construction of the port was started as a project under the direct control of the national government.

In April 1978, Hokkaido Prefecture, Otaru City, and Ishikari City together formed the Ishikari Bay New Port Authority to oversee construction and maintenance of the port. Under the new administrative authority, construction of port facilities has been methodically carried out beginning with the East District. Development projects are planned over the entire approximately 3,000 hectares of the Ishikari Bay New Port Area. Fig. 8 shows dunes along the Ishikari coast. Figs 9 and 10 show the location and panoramic views of Ishikari Bay New Port. Figs 11 and 12 show the facilities and layout of Ishikari Bay New Port. Fig. 13 shows various harbor facilities at Ishikari Bay New Port [9]-[11].

\section{CHANGES AT THE ISHIKARI RIVER MOUTH}

Fig. 14(a)-(d) shows maps of the Ishikari River mouth in 1893, 1909, 1996 and 2008, respectively, and Fig 15 shows the changes at the Ishikari River mouth in 1874 to 1970 [12][16]. Fig. 16 (a)-(c) is the changes of spit at the Ishikari River mouth in 2009-2010, and spits were moving toward sea from river side [17]. 


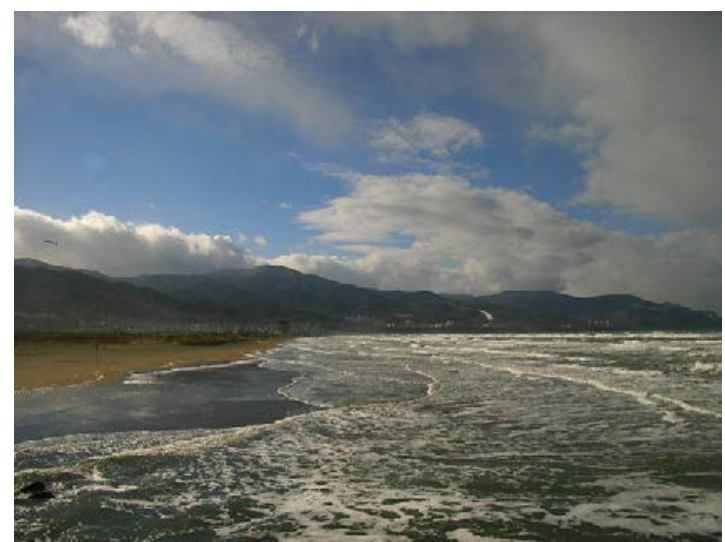

Figure 8: Dunes along the Ishikari coast.

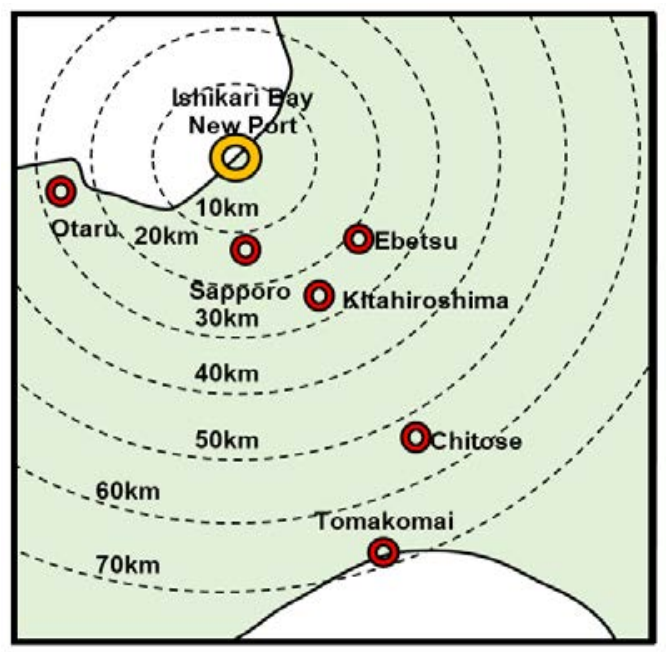

Figure 9: Location of Ishikari Bay new port.

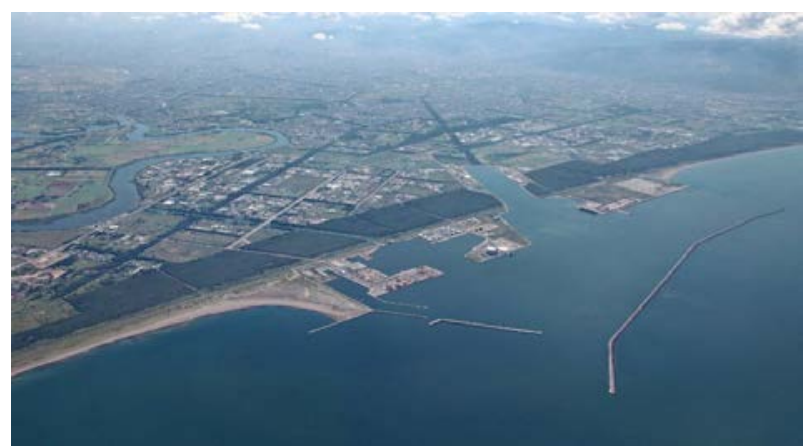

Figure 10: Aerial view of Ishikari Bay new port. 


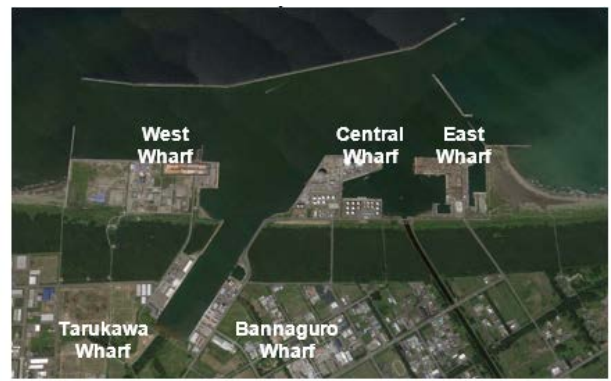

Figure 11: Facilities of the Ishikari Bay new port.

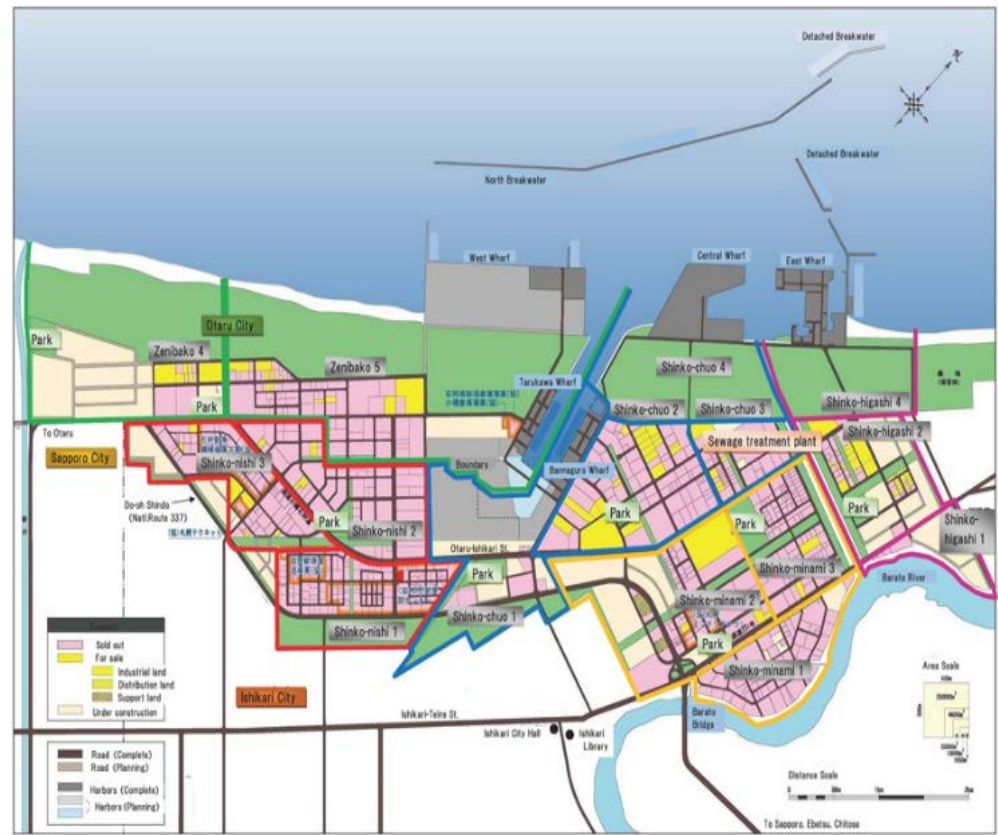

Figure 12: Layout of Ishikari Bay new port [12].

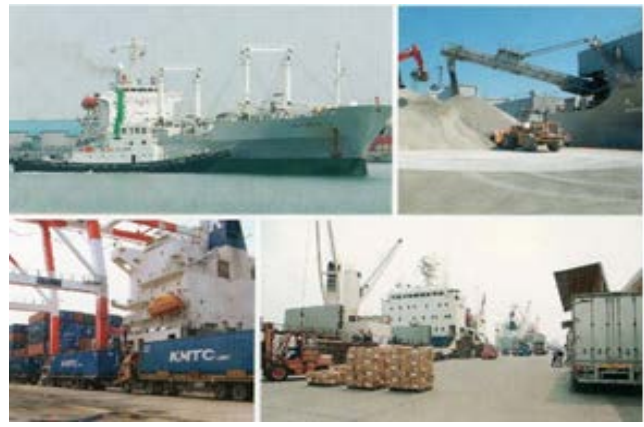

Figure 13: Facilities at Ishikari Bay new port. 


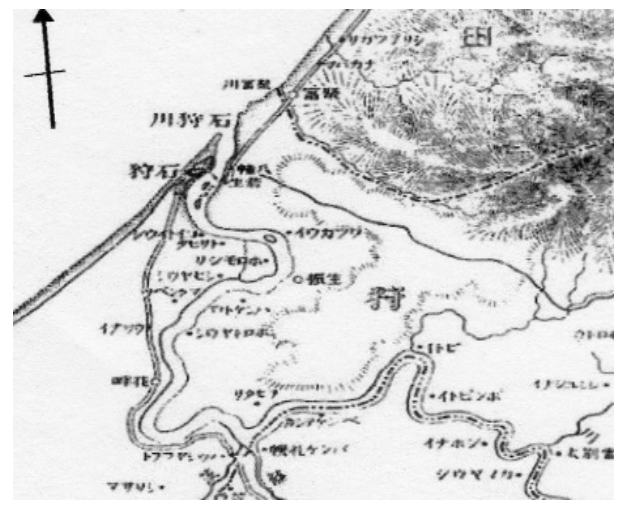

(a) 1893

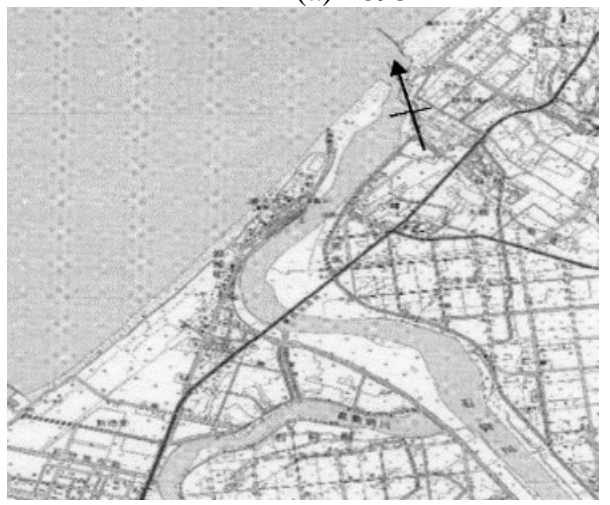

(c) 1996

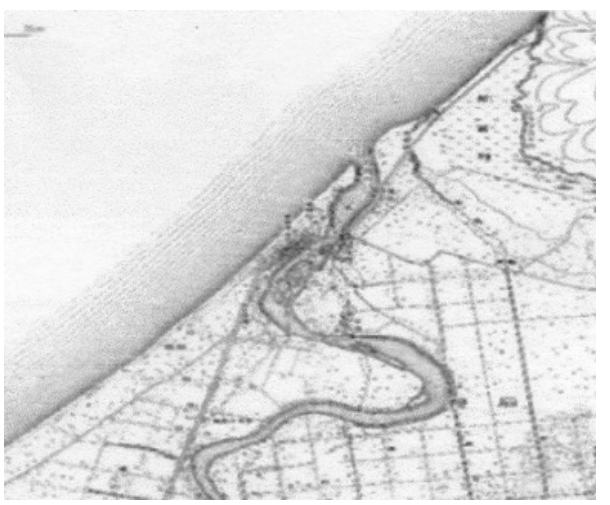

(b)1909

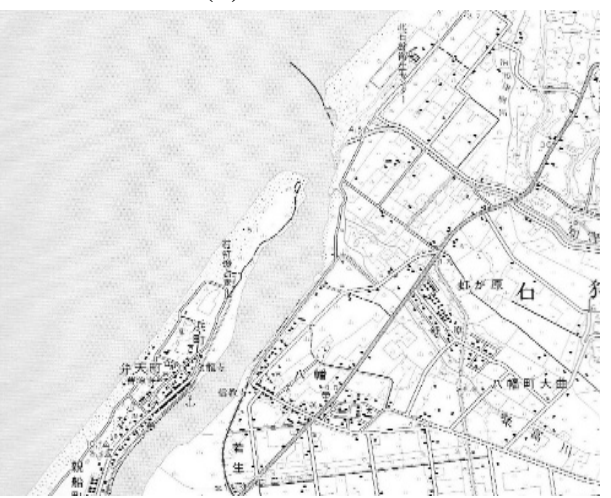

(d)2008

Figure 14: Change of around Ishikari River mouth.

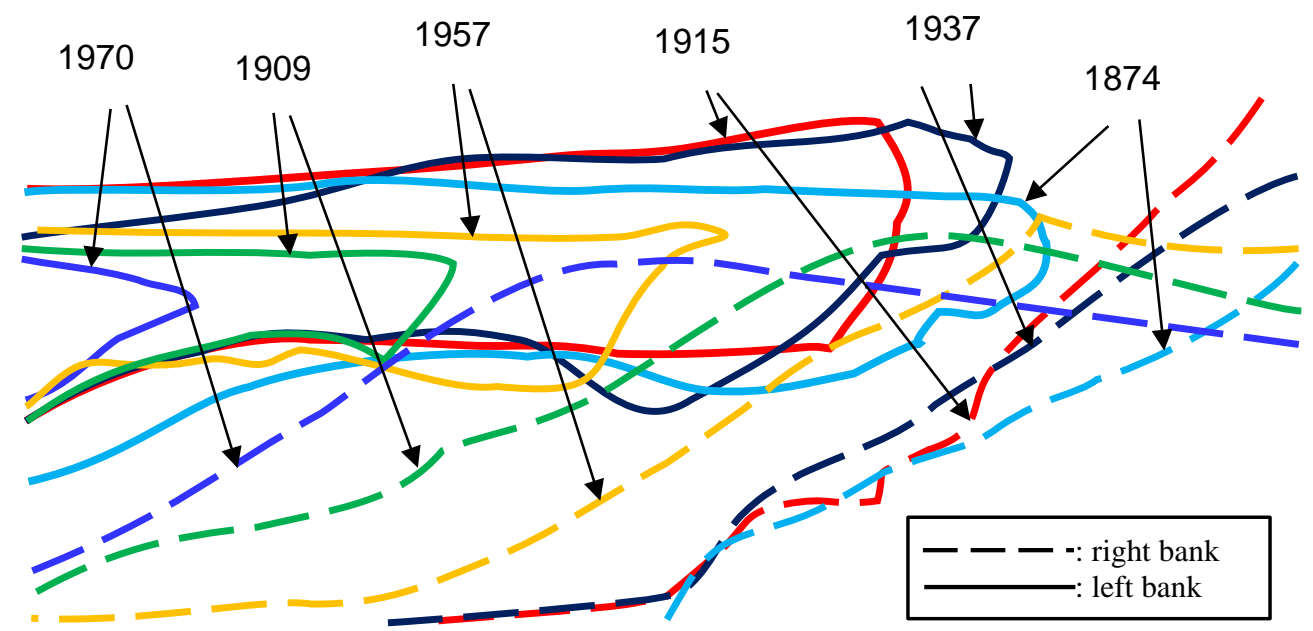

Figure 15: Changes of Ishikari River mouth (1874-1970). 


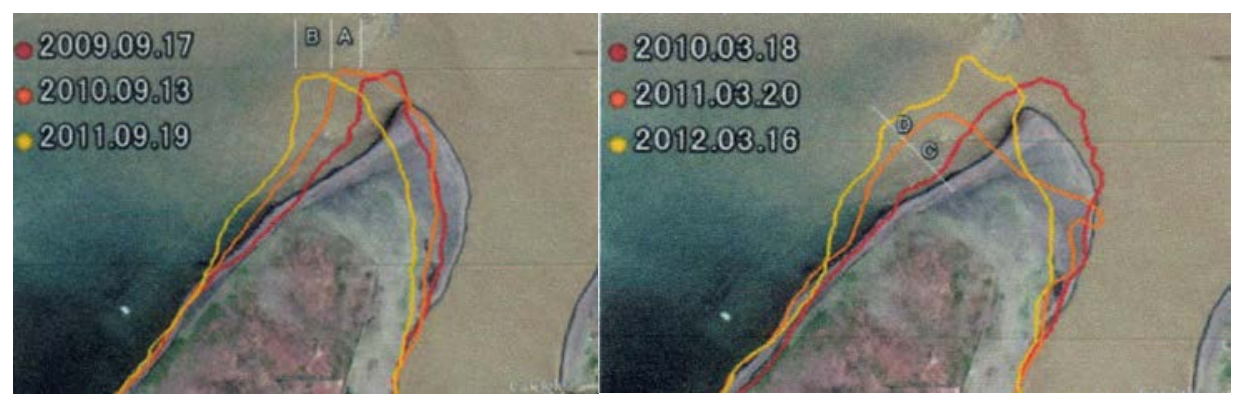

(a) Changes from 2009/9/17-2011/9/19.

(b) Changes from 2010/3/18-2012/3/16.

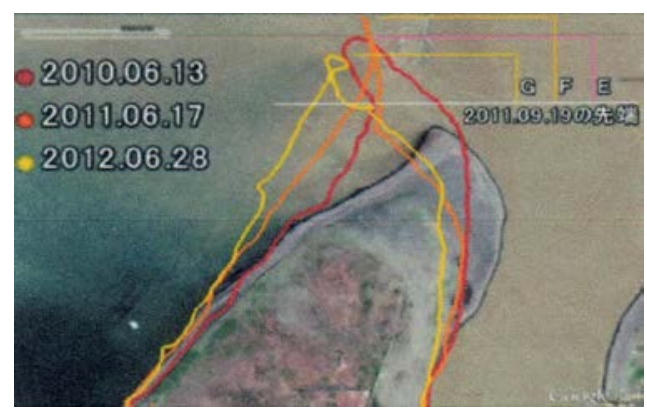

(c) Changes from 2010/6-2012/6.

Figure 16: (a)-(c): changes of Ishikari River spit.

\section{STUDY RESULTS}

The size of a drainage area of Ishikari River is the second area in Japan and covers 1/6 of the land area of Hokkaido and is home to half of the population of Hokkaido. The vast meadow of this basin had been changed by the flood control measures for the Ishikari River though part of the area was affected by extensive flood hazards in 1975 and 1981.

The main causes of flood hazards are heavy rain events, river mouth closure and drainage. River mouth closure is affected by longshore currents and the river flow rate in addition to sediment loading. Many countermeasures for river mouth closure had been carried out but with limited effectiveness. Through construction of the Ishikari Bay New Port, the river mouth of Ishikari River stabilized and river mouth closure was reduced due to reduced longshore sediment transport.

\section{REFERENCES}

[1] Encyclopedia Britanica, Spit, 2016. Online. https://global.britannica.com/place/ Ishikari-River.

[2] Kawamura, I. \& Tanaka, H., Recent Morphological Change at the Naruse River Mouth, Japan, International Conference on Estuaries and Coasts, 2016, Online. https://www.researchgate.net/publication/237744951_RECENT_MORPHOLOGICA L_CHANGE_AT_THE_NARUSE_RIVER_MOUTH_JAPAN.

[3] Encyclopedia Britanica, Ishikari river, 2016, Online. https://global.britannica.com/ place/Ishikari-River. 
[4] Asahi, K. et al., Estimation of Sediment Discharge Taking into Account Tributaries to the Ishikari River. Journal of Nature Disaster Science, 25(1), pp. 17-22, 2003.

[5] Tanaka, M., The transition of Ishikari coast, Text of Ishikari Citizen's College, Ishikari workshop, (in Japanese), 2014.

[6] Mapple, Atlas Japan, Shoubunsha, (in Japanese), 2010.

[7] Hokkaido Development Agency of the Japanese Government, Outline of the Ishikari River Basin, 2017, Online. www.sp.hkd.mlit.go.jp/kasen/09kawazukuri/06ikusyun/ pdf/.

[8] Ministry of Land, Infrastructure and Transportation, Ishikari River Mouth and Japan, Flood Control 100 Years, 2016, Online. www.sp.hkd.mlit.go.jp.634x467.

[9] Tomaki, S., Kubota, S. \& Takezawa, M., Reconsideration about changes of coastal section topography around the Ishikari Bay New Port. Proceedings of Ocean Development, JSCE, 20, pp. 497-502, (in Japanese), 2005.

[10] Ministry of Land, Infrastructure and Transport, Maintenance Plan of Ishikari River, 2016, Online. http://www.sp.hkd.mlit.go.jp/kasen/09kawazukuri/02seibi.

[11] Ishikari Bay New Port Authority. Ishikari Bay New Port, Closest port, to Sapporo, 2016, Online. http://www.ishikari-bay-newport.jp.

[12] Ishikari Development Co. Ltd, Ishikari Bay New Port, 2016, Online.

[12] www.ishikari-dev.co.jp/en/ishikaribay.html.

[13] Ishikawa, O., The Estuary of Ishikari River, Text of Ishikari Citizen's College, Ishikari workshop, (in Japanese), 2014.

[14] Hiraoka, A., Hokkaido, 100 Years Writing Map, Kokin shoin, (in Japanese), 2004.

[15] Geographical Survey Institute, Map of Ishikari, Geographical Survey Institute, 2009.

[16] Kamiyama, T., Ogyu, Y. \& Yoroitani, M., Report of groin works at the Ishikari River mouth, Civil Engineering Research Institute for Cold Region, 1973, Online. thesis.ceri.go.jp/db/documents/public-detail/2663.

[17] Ishikawa, O., Survey of the morphological changes of Ishikari estuarine spit by GPS logging, Online. www.city.ishikari.hokkaido.jp/museum/pdf/ilm-bulletin 003. 